\title{
A palarvra e a revolução: Rafael e o convento da poesia de Manuel Alegre
}

\author{
Paulo Ricardo Kralik Angelini*
}

Resumo: Narrativa de incertezas, teia construída a partir de textos outros, recordações e divagações, Rafael configura-se como uma obra em que as palavras vinculam-se com uma essência libertária. Em um jogo de espelhos, as inúmeras referências intertextuais iluminam-se e refletem em outras imagens, tendo em foco um regime totalitário e as consequentes aniquilações do indivíduo, que se fragmenta. Este artigo investiga as artimanhas narrativas desenvolvidas pelo escritor Manuel Alegre na construção dos caminhos de um português que se descobre sempre rumo a Lisboa, por mais que suas trilhas levem-no para outros lugares.

Palavras-chave: Manuel Alegre, Rafael, Portugal, Revolução dos Cravos, Narrador, Intertextualidade, Wayne Booth, Lisboa

“A poesia é uma pátria, em qualquer língua do mundo porque nenhuma é estrangeira" (ALEGRE, 2004, p. 118)

O escritor Urbano Tavares Rodrigues, em suas lúcidas incursões pela crítica literária, aponta a "Resistência, revista à luz clara da liberdade", como um dos temas caros à literatura portuguesa depois do abril de 1974. Os duros anos de um quase confinamento à força por conta da violência e da opressão salazaristas trazem, em seu vácuo, uma longa discussão acerca das personagens - históricas ou não - que juntas participaram da Revolução dos Cravos: "Pedro logo encaminha-se para a casa onde vai ser preso dentro de momentos, são três da madrugada do dia 24 de abril de 1974" (Ibidem, p. 241).

Em Rafael (2004), obra de Manuel Alegre (1936), um homem luta pela mudança do mundo. Um homem sai de seu país, assume-se num exílio na França enquanto manobra, com seus camaradas, uma quase utópica revolução: "Sim, quando eu me dei conta, eu estava na História, metido no verbo acontecer até ao osso, até ao avesso, até doer, eu estava na História e a História estava na vida e uma e outra estavam na escrita..." (ALEGRE, 2004, p. 39). É na força da palavra que este homem constrói não apenas a resistência, mas também a tentativa de mudança. E é, portanto, a sua palavra traduzida, percorrida, entrelaçada com palavras outras que compõem o repertório revolucionário deste português. Este homem é Rafael, alguém que abandona Coimbra e suas raízes em busca do sonho: "Uma última vez olhou para Coimbra, dessa Coimbra me despeço, escrevo eu agora" (Ibidem, p. 76).

Personagem-narrador-autor embaralham-se no campo da construção literária, extrapolando as fronteiras canônicas tradicionalmente compartimentadas. Típica característica de grande parte das obras contemporâneas portuguesas, Rafael apresenta um narrador desestabilizador, que chama o leitor para o jogo textual, apresentando suas - sutis ou não - artimanhas para conquistá-lo. Do ponto de vista do foco narrativo, percebe-se um narrador que transita entre a terceira e a primeira pessoas do singular. Em alguns capítulos, há um pretenso distanciamento, porque sempre fingido: "Rafael pede a palavra" (Ibidem, p. 33). Em muitos momentos, essa tática procura caracterizar um personagem que não se enquadra em estereótipos: "Não, decididamente Rafael não é um homem de fé, nem de dogma, nem de seita, não saiu de um totalitarismo para cair em outro..." (Ibidem, p. 97). Abocanhando a técnica do narrador digno de confiança (para depois subvertê-la), pega o leitor pela mão e oferece uma caminhada aparentemente tranquila dentro da narração: "Aí

* Doutor em Literatura Portuguesa (UFRGS), professor do Instituto de Letras da UFRGS. 
vão eles, o Alferes e o Capitão..." (Ibidem, p. 49). Oferece, igualmente, uma certa precisão temporal, a marcar este dia chave de um tempo histórico muito bem constituído: "São quase duas horas da manhã do dia 25 de abril..." (Ibidem, p. 252).

Em outros capítulos, porém, há o conflito entre esse distanciamento do narrador. Numa mesma página, surgem a terceira pessoa - "Para Lisboa se partiram, Rafael e Geraldes da Veiga, seu pai..." (Ibidem, p. 75) — e a primeira - "Digo adeus à cidade, de certo modo despeço-me de mim, Rafael Gonçalves da Veiga, eu próprio, tantos outros" (Ibidem, p. 75). Há, ainda, numa mesma frase, a mudança da pessoa da narrativa, como na já citada passagem: "Uma última vez olhou para Coimbra, dessa Coimbra me despeço, escrevo eu agora" (Ibidem, p. 76). O leitor desatento talvez pudesse não perceber essas alterações da pessoa verbal; todavia, um leitor desatento não interessa a Rafael, o personagem. Logo, o narrador grita, chamando-o para os possíveis conflitos de "dispersão do eu" de Rafael, montando seu jogo metaficcional: "Agora tenham paciência, não é possível continuar na terceira pessoa, volto à primeira, ainda que seja Rafael Gonçalves da Veiga, o outro, quem está em cena" (Ibidem, p. 78).

O narrador cita Rafael como o outro porque traz rastros da biografia do próprio autor real, Manuel Alegre. Aliás, pode-se também afirmar ser esta uma característica comum de parte da literatura contemporânea portuguesa, e basta aqui trazer a lembrança das obras de Helder Macedo e Baptista-Bastos. O narrador de Rafael faz questão de confundir ao tentar explicar como entra a História na história, a biografia na ficção, numa construção de personagens que remete à obra de Fernando Pessoa: "Foi a História que lhe entrou portas adentro e tomou conta dele, Rafael Gonçalves da Veiga, eu próprio, o outro. Não tinha sequer a possibilidade de se refugiar num qualquer heterônimo, inventar-lhe uma biografia, outra vida, outra escrita" (Ibidem, p. 36). Desta forma, o narrador assume-se com consciência de si próprio, aquilo que Wayne Booth estabeleceu como um narrador dramatizado em The Rethoric of the fiction. Mais que isso, assume-se também autor, numa tentativa de estabelecer com o leitor um pacto de confiança, desde já rompido ao lembrar as tênues fronteiras entre História e ficção:

Talvez tenha sido por causa de encontros-desencontros que se pôs a escrever, não a obra circular em torno do número 100, mas esta história aos quadradinhos, espécie de rimance popular adaptado a telenovela, ou, se preferem, esta epopéia do avesso que é o romance da História por que foi invadido misturado com a que vulgarmente se chama a história da minha vida, até podia ser o título deste livro, se por acaso alguém fosse capaz de saber onde acaba a História com Agá Grande e começa a outra com agá pequeno, ou simplesmente onde começa a realidade e acaba a ficção, que é como quem diz o que é biografia e o que é romance. Ou seja: a vida, isto que passa (Ibidem, p. 73).

Ao trazer a vida como uma obra a ser escrita — "E desta vez não me despeço, sou um alferes miliciano, há guerras que não acabam nunca, elas são a vida, elas são a escrita, afastai de vós o cepticismo e os micróbios, a página está em branco e o nosso destino é cavalgar, cavalgar, cavalgar" (Ibidem, p. 40) —, o narrador expõe os próprios mecanismos da construção literária, nunca deixando à parte o dilema realidade versus ficção: "A página, a rua, a vida. Onde acaba esta, onde começa a escrita?" (Ibidem, p. 148), observando-a sempre com o viés da História: "Foi aí que começou a descer da torre de marfim da escrita como fim de si mesma, o que, diga-se desde já, ela é sempre, mesmo quando a História a invade com seus atropelos, suas botas, sua interpelação e sua urgência" (Ibidem, p. 37).

Outras vezes, o narrador apresenta os problemas da autoria, avisando ao leitor que não se adentrará por tal terreno para evitar maiores confusões: "Eu podia contar, porque já lá o provei, como é bom o patê de canard, que Adolfo todas as semanas recebe da França. Mas isso levaria tempo e poderia levantar suspeitas sobre quem é quem nesta história" (Ibidem, p. 252). Entretanto, em Rafael, a confusão é desde sempre estabelecida. O narrador pede ao leitor que acredite no que conta, fazendo juramentos explícitos - "Juro que isto não é ficção, há uma americana vinda não se sabe de onde, talvez do futuro filme de Godard" (Ibidem, p. 74), "não lhes vi a cara mas quase posso jurar quem eram, até tenho medo de dizer, aparição ou não, pouco importa..." (Ibidem, p. 69), "- Viver é um perigo, responde ele a sorrir, palavra de honra que foi o que ele disse: Viver é um perigo" (Ibidem, p. 82) — e, na mesma medida, defende-se de prováveis desconfianças: "Eu quase posso jurar que sei quem são, mas se o disser ainda vão acusar-me de misturar história e ficção, alhos e bugalhos, verdade e fingimento, como se assim não fosse a própria vida, a escrita" (Ibidem, p. 14).

Nestas conversas diretas com o leitor, rompe as fronteiras romanescas, típico de um narrador que procura a desestabilização de um interlocutor: "Não me venham com tretas nem citações..." (Ibidem, p. 99) e em: "Que andou sempre comigo, na guerra, na cadeia, está aqui na carteira, reparem, é mais do que uma lasca de madeira, é o Pinheiro das Sete Cruzes, o meu nome é Catafula" (Ibidem, p. 120). Em muitos momentos, o narrador de terceira pessoa, que o leitor já sabe ser o mesmo Rafael, conversa com ele próprio, articulando um

Organon, Porto Alegre, nº 47, julho-dezembro, 2009, p.163 - 175 
interessante discurso em segunda pessoa do singular. Junto a isso, outra vez o narrador revela seus planos de esconder material que pode não ser de interesse do público em geral, mas apenas do personagem, uma espécie de único leitor: "Esta parte da vida é só tua. Ninguém vai querer saber. Mais tarde, quando quiseres contar, mudarão de conversa. Mesmo os teus. Não há outro remédio senão escrever como se a ti próprio estivesses a contar-te. A guerra, a prisão, o salto, o exílio" (Ibidem, p. 131).

As incertezas do narrador são, desde o início da obra, expostas. Já no pequeno texto que inaugura Rafael, há a quebra do espaço e do tempo. E da própria realidade: "Perdi a mala mais uma vez. Estou no aeroporto branco de uma cidade branca. (...) Talvez esteja a sonhar. Talvez não esteja. Talvez esteja acordado dentro de um sonho..." (Ibidem, p. 9). O narrador nem sempre tem total certeza dos fatos que relata e despeja expressões dubitativas: "Ou talvez haja..." (Ibidem, p. 105), "o mesmo comboio onde, por acaso, ou talvez não, vai" (Ibidem, p. 105), "Mas talvez seja possível que sim, mais tarde tudo pode ter acontecido, quem sabe se não é verdade que uma brigada esteve duas horas antes na cafeteria..." (Ibidem, p. 13), "Mas quem sabe afinal em que sentido, quem sabe se sim, quem sabe se não?" (Ibidem, p. 17). Mesmo ao autor implícito, em certas passagens exposto numa instância diferente da do narrador, escapam certos elementos básicos, como o conhecimento de um dado personagem: "É ele que vai sentado ao lado do condutor, tão clandestino que nem o Autor sabe quem é, sequer o pseudônimo..." (Ibidem, p. 247). Há momentos em que o narrador assume-se dispensável: "Ricardo Garcia, que não precisa que ninguém por ele fale, ele próprio conta: - Estive na guerra colonial em Moçambique..." (Ibidem, p. 113), para em seguida complementar, visto que o diálogo do personagem não foi suficiente para a sua apresentação: "Falta-lhe acrescentar que foi um dos principais dirigentes da revolta estudantil de 1962" (Ibidem, p. 113). Em outras passagens, mostrando o poder da narrativa nas mãos, o narrador adianta os acontecimentos ao leitor: "Mais tarde vão fazer deste episódio uma lenda..." (Ibidem, p. 78), "Mas isso ainda não o sabe" (Ibidem, p. 35), "Haverá mais tarde outras versões" (Ibidem, p. 71), "Só na manhã seguinte se saberá" (Ibidem, p. 182).

No hábil jogo da escrita que (des)constrói, o próprio narrador-autor avisa o leitor sobre a magia da palavra: "(Rafael) acredita na força da palavra, na repetição da estrutura rítmica da oração, do poema ou do que quer que seja" (Ibidem, p. 74). Desta maneira, há, sim, exposta, a repetição rítmica, dialogando com outros discursos, como o religioso, aqui a denunciar os horrores da guerra: "Rezai, rezai, vós que sabeis. Rezai, rezai, vós que não quereis saber. Rezai, rezai, vós que fingis que não sabeis" (Ibidem, p. 65). Igualmente há a própria repetição de eventos, como a sua despedida de Coimbra, trazida duas vezes: "É quase às escondidas que Filipa de Vasconcelos, sua avó, lhe entrega os cinquenta contos, é quase em segredo que sua mãe chora quando ela diz: "Toma, vais com certeza precisar e eu nunca mais voltarei a ver-te" (Ibidem, p. 74), episódio já antes relatado: "Não se conteve quando Filipa, minha avó, me entregou cinquenta contos: Toma, disse, vais com certeza precisar e eu nunca mais voltarei a ver-te" (Ibidem, p. 13-14). Há também a força da palavra, envolvida em ritmos que exploram o poético, em aliterações de consonância: “....as folhas a boiar, rosas de outras eras, ecos, restos, rastros" (Ibidem, p. 18). Palavras e frases construídas que nunca tentam escamotear a vida real, mesmo que travestida de romance, como tenta provar o narrador: "É preciso viver perigosamente. Frases de cinema ou romance. Agora tudo se tornou perigoso. Estou a viver perigosamente, mas não é um filme, é a vida, que é como quem diz: um romance" (Ibidem, p. 79).

Há inovações estilísticas em Rafael, como uma sequência de capítulos em que o narrador, a brincar de câmera cinematográfica, acompanha os personagens - "Agora vão de Lausana para Genebra enquanto no comboio de Paris está quase a chegar" (Ibidem, p. 109) - e deixa o texto em suspenso para a próxima página, sem ponto final: "Daniel. Ou talvez Fernão Mendes Pinto. Ninguém fez uma tão grande peregrinação revolucionária..." (Ibidem, p. 110).

Ao trazer a imagem de Fernão Mendes Pinto, o narrador apresenta o maior trunfo de seus relatos: o poder da palavra a serviço da intertextualidade. O exílio e o trânsito a outros países arranharam a sua identidade: "Perderei o nome, os sítios amados, a areia branca, o cheiro a Atlântico do meu país. Sou eu e não sou eu. Uma parte de mim vai saltar, a outra não" (Ibidem, p. 80). O narrador sente-se estrangeiro, e isso é repetido à exaustão: "Tudo ficou para trás, eu próprio tenho a sensação de ter ficado para trás, sinto-me estrangeiro dentro de mim mesmo" (Ibidem, p. 83), "Preparo o passaporte, faço-o sempre como se de mim mesmo suspeitasse, não é meu nome, nem o meu rosto antigo, nem a minha nacionalidade, de certo modo sou um estranho, mais que estrangeiro um estranho, eu é um outro, um outro é eu, quem eu sou não tem papéis, quem os tem não sou eu..." (Ibidem, p. 154). Com sua própria alma em aberto, Rafael preenche-se pelo literário, uma vez que o poético não tem pátria, é livre e de todos: "Perderás os sítios, o nome, a língua, a areia branca, o cheiro a Atlântico do teu país, estás a emigrar para dentro dos poetas franceses, Sous le Pont Mirabeau coule la Seine, a poesia é uma pátria, em qualquer língua do mundo porque nenhuma é estrangeira" (Ibidem, p. 118).

Organon, Porto Alegre, n 47, julho-dezembro, 2009, p.163-175 
Há inúmeras citações construídas no texto, e todas obedecem a uma lógica de resistência, trazendo desde líderes revolucionários ${ }^{1}$ a papas da cartilha esquerdista, como Marx, Brecht, René Char ${ }^{2}$, Óssip Mandelstam ${ }^{3}$, a reforçar a ideia de que pela literatura começa-se toda e qualquer revolução. Rafael incorpora os personagens: "O meu nome é Hamlet, um fantasma me persegue, uma pergunta" (Ibidem, p. 26) ${ }^{4}$, o que fica claro na seguinte passagem: "Pela noite fora se conversava, cada um deles representando a personagem de que se apropriara ou que deles se apossara. Porque também havia esses: Os possessos, ora na versão de Dostoievski, ora na peça de Camus" (Ibidem, p. 32). Aliás, há destaque para a intertextualidade com a literatura russa e a francesa. Da primeira, recupera, além de Dostoievski, Alexandre Blok ${ }^{5}$, Vladimir Maiakovski e Tolstoi.

Dos franceses, o repertório é vasto. Um, em especial, funciona como eixo da própria narrativa: Roland Barthes. São duas as passagens que merecem destaque, dialogando com a morte do autor e com o grau zero da escrita: "Seria provavelmente mais interessante dissertar sobre o 'Prazer do texto' em qualquer tertúlia de Lisboa. Do texto sem autor e do autor sem biografia, só destino. Mas Rafael não tinha outro remédio senão o dos versos que trazia dentro dele. Talvez fosse o destino. E estava, sem o saber, a fazer biografia" (Ibidem, $p$ 60) e "Há tanta história para contar, tanta que não se contou. Está uma página por escrever, algures, dentro de nós. É o grau zero da escrita" (Ibidem, p. 64). Camus e Sartre ${ }^{6}$ também têm papel importante no jogo intertextual de Manuel Alegre. Contudo, é Rimbaud quem traz um verso chave à obra: Je est un autre ${ }^{7}$ : "Estrangeiro é morar no verso de Rimbaud, Je est un autre, ser eu e não ser eu e não saber ao certo que outro se é ou se vai ser" (Ibidem, p. 96). Desfilam, ainda, Breton e sua Nadja ${ }^{8}$, Malraux ${ }^{9}$, entre outros poetas.

O espanhol Federico Garcia Lorca é outro nome chave na obra, por sua poesia politizada e pela palavra bruxa. De Lorca ${ }^{10}$, o narrador recupera especialmente o texto Teoría y juego del duende, transcrito de uma célebre conferência de 1933, em Buenos Aires. Há, inclusive, uma transposição espacial entre Coimbra e Granada: "Olhas num reflexo da Lua e então Coimbra não é Coimbra, é Granada, o último eco da guerra

\footnotetext{
1 "O meu nome é Jean Moulin..." (Ibidem, p. 23). Moulin era um dos chefes da resistência francesa contra a ocupação alemã durante a Segunda Guerra Mundial. Também Henrique Galvão, capitão português e um dos responsáveis pela tomada da embarcação Santa Maria, em 17 de Fevereiro de 1961, quando essa se preparava para acostar no Cais de Alcântara, é lembrado. O navio, propriedade da Companhia Colonial de Navegação, foi tomado por oposicionistas ao governo salazarista em 22 de Janeiro de 1961: "Para já não falar no Santa Maria, durante uns dias ele foi Henrique Galvão ao leme do Santa Liberdade. Era impossível fugir à História. (...) - Temos o Santa Maria conosco, obrigado, portugueses" (Ibidem, p. 37).

2 "René Char, guerrilheiro e poeta, bem o sabia: há guerras que não acabam nunca. (...) O francês bem avisou: "Afastai de vós o ceticismo e a resignação, e preparai a vossa alma mortal para afrontar intramuros os demônios gelados análogos que têm o tamanho de micróbios"” (Ibidem, p. 40). Referência ao francês René Char, pouco conhecido em Brasil e Portugal, poeta, crítico e curador de artes, militante político, filósofo e pesquisador das linguagens visuais e verbais. Nascido em 14 de junho de 1907, numa propriedade rural em Névons, Isle-sur-la-Sorgue, nos arredores de Avignon, na região da Provença, no sul da França.

3 "E sabe o que é um poeta? Um poeta é aquele que desobedece às ordens. Um poeta, disse outro poeta a caminho de um campo de concentração, chamava-se Mandelstam, era russo, aposto que nunca ouviu falar, quando estava absolutamente perdido disse à sua mulher: A poesia é o poder. Foi assim que ele disse, a poesia é o poder, por isso é que os ditadores nos mandam prender e nos mandam matar..." (Ibidem, p. 46). Referência a Óssip Mandelstam, nascido na Polônia, em 1891, descendente de uma família judia, que viveu em S. Petersburgo, seguindo mais tarde para Paris. Em 1933, escreve a obra que mudaria os rumos de sua vida, um poema satírico sobre Stalin, que quase lhe rendeu uma pena de morte. Passa os últimos anos de sua vida na prisão.

${ }^{4}$ Ainda de Shakespeare, Rafael traz a imagem de Ofélia: "Mas é numa rua de Coimbra, numa noite branca e fria, que sinto por dentro a morte de Ofélia e os ventos da Noruega que sopram no poema de Rimbaud. Amarei essa imagem de virgem louca lentamente flutuando, deitada nos seus longos véus" (Ibidem, p. 26).

5 "Ninguém ao certo sabe quem é a bela dama desconhecida de todas as grandes capitais, nem mesmo Alexandre Blok, pergunto quem tu és, mas a resposta é indecisa" (Ibidem, p. 203). Referência a um dos grandes poetas russos do século XX, Alexandre Blok (1880-1921), que também foi à guerra e desempenhou um papel marcante na revolução russa.

6 "O que se lia era Camus e Sartre, era essa a divisão, camusianos, sartrianos. Rafael preferia Camus, O Estrangeiro, essa metáfora do homem alheio ao mundo, à regra, a si mesmo, essa escrita quase neutra" (Ibidem, p. 31).

${ }^{7}$ Das cartas entre Rimbaud e Paul Demeny, datadas de 1871.

8 "A Nadja de Breton" (Ibidem, p. 19) e "Ou talvez Breton: o acaso" (Ibidem, p. 213). Nadja é um texto surrealista (1928) do poeta francês André Breton (1896-1966).

9 "Rafael pensa no romance de Malraux: A greve geral não será decretada em Cantão (Ibidem, p. 185) Referência à obra $O s$ Conquistadores, de 1928, de André Malraux (1901-1976).

10 "E havia Lorca, havia o duende, havia a batida da terra que eu não sabia ainda que era a batida do flamenco e da escrita. Nos rebordos da ferida, dizia Lorca" (Ibidem, p. 28) e "Rafael pensa em Lorca e na sua Teoria do Jogo e do Duende, um dos mais extraordinários textos que jamais leu, escrito num tempo em que ainda se acreditava na força bruxa da palavra" (Ibidem, p. 240). Um trecho da citada conferência: "Estos sonidos negros son el misterio, las raíces que se clavan en el limo que todos conocemos, que todos ignoramos, pero de donde nos llega lo que es sustancial en el arte. Sonidos negros dijo el hombre popular de España y coincidió con Goethe, que hace la definición del duende al hablar de Paganini, diciendo: "Poder misterioso que todos sienten y que ningún filósofo explica». Así, pues, el duende es un poder y no un obrar, es un luchar y no un pensar. Yo he oído decir a un viejo maestro guitarrista: «El duende no está en la garganta; el duende sube por dentro desde la planta de los pies". Es decir, no es cuestión de facultad, sino de verdadero estilo vivo; es decir, de sangre; es decir, de viejísima cultura, de creación en acto" (LORCA, Internet).
}

Organon, Porto Alegre, nº 47, julho-dezembro, 2009, p.163-175 
civil" (Ibidem, p. 28). As batidas do flamenco também são cantadas, a partir da famosa canção lorquiana: "Empieza el llanto de la guitarra. Es inútil callarla. Es imposible callarla" (Ibidem, p. 28).

Outro poeta diversas vezes recuperado por Rafael é o tcheco Rainer Maria Rilke ${ }^{11}$. De outras literaturas traz o alemão Friedrich Hölderlin e o espanhol Jorge Semprum ${ }^{12}$, os italianos Dante Alighieri e Guido Cavalcanti ${ }^{13}$, e ainda Kafka e Stendhal ${ }^{14}$. Com Thomas More há uma interessante passagem que se entrelaça com o nome do personagem:

No prefácio de Utopia, Thomas More diz que foi um marinheiro português chamado Rafael que, numa taberna de Amsterdão, lhe falou dessa ilha perfeita. Onde ficava ele não disse. Então Thomas More chamou-lhe Nusquama, palavra que, em latim, significa Em parte alguma. Erasmo, que era amigo dele, aconselhou-o a substituí-la pela palavra grega Utopos, que quer dizer a mesma coisa (Ibidem, p. 233).

Há também espaço para a filosofia. Rafael traz uma das mais famosas teses de Marx, que conclama à saída do mundo das ideias para a ação prática: "os filósofos não têm senão interpretado o mundo, agora é preciso transformá-lo" (Ibidem, p. 212). No repertório de Manual Alegre, há o persa Omar Kayham ${ }^{15}$, Hegel e Nietzsche. Há canções e poesia na voz de Leo Ferré ${ }^{16}$. Do cinema ${ }^{17}$, close em Vittorio de Sica, Monica Vitti, Erroll Flynn e na Pandora de James Mason e Ava Gardner.

Contudo, evidentemente que é com a literatura portuguesa o maior entrecruzamento. Literatura que, a todo momento, tem papel também político, fato esse sublinhado pelo próprio narrador: "Também há poetas portugueses que estão a abater Salazar verso a verso" (Ibidem, p. 53). A Coimbra de Eça de Queiroz e Antero de Quental é recuperada: "Passo depois pela Sé Nova, sento-me nos degraus, meu nome é Eça e digo em voz alta: Esta encantada e fantástica Coimbra. Estou a ver Antero, declama, gesticula, desafia Deus, ainda não chegou à língua nova dos sonetos" (Ibidem, p. 19) ${ }^{18}$. Há igualmente uma forte lembrança da figura do poeta Mário de Sá-Carneiro:

\footnotetext{
11 "Sentado sobre o rio entro na Torre de Duino a ler as Elegias, vou com Rilke pelo parque, ele fala da morte própria que cada um traz dentro de si como um fruto" (Ibidem, p. 19) e "Queria entrar para o convento da poesia, construir os grandes arcos de solidão de que fala Rilke, fazer da linguagem uma espécie de pátria ou de exílio" (Ibidem, p. 36). A primeira citação é referência à obra em prosa mais famosa de Rilke (1875-1926): Os Cadernos de Malte Laurids Brigg: "Antigamente sabia-se (ou talvez se pressentisse) que se trazia a morte dentro de si, como o fruto o caroço. As crianças tinham dentro uma pequena e os adultos uma grande. As mulheres tinham-na no seio e os homens no peito. Tinha-se, a morte, e isto dava às pessoas uma dignidade particular e um calmo orgulho" (RILKE, Internet).

12 "Já antes, desde a consciência de si, sempre sentiu aquilo a que Hölderlin chamaria o exílio da casa do ser, o sentimento de ser estrangeiro no mundo, no qual, conforme muito depois lerá em Semprun, talvez tenha origem a própria literatura" (Ibidem, p. 35). Referência ao poeta Friedrich Hölderlin (1770-1843), cuja produção literária é pequena, compreendendo uma tragédia inacabada, Tod des Empedokles (A Morte de Empédocles), um romance epistolar Hyperion ou O Eremita da Grécia e, sobretudo, as suas poesias, que lhe deram fama. Jorge Semprum, escritor espanhol, nascido em Madrid em 1923 e com vasta atuação na política. Entre 1953 e 1954, foi militante e depois dirigente do Partido Comunista espanhol, sob o pseudônimo Federicio Sánchez. Foi ministro da Cultura no governo socialista de Felipe Gonzáles, entre 1988 e 1991.

13 "Invoca o seu mestre Dante" (Ibidem, p. 72) e "Donna mi prega, perc'hio voglio dire / d'un accidente, che sovente è fero, meu nome é Guido Cavalcanti, troquei sonetos com Dante...” (Ibidem, p. 133). Guido Cavalcanti era poeta e amigo pessoal de Dante. Há referência de Guido no canto X de Inferno, da Divina Comédia. E os versos fazem parte de um dos poemas mais famosos de Cavalcanti.

14 "Resiste ao sentimento, segue a lição de Stendhal, prosa de código civil, ou a de Kafka, neutra" (Ibidem, p. 135), "Burocracia parece saída das páginas de Kafka..." (Ibidem, p. 92-93).

15 "Naquele crepúsculo não há cadáveres enlaçados em redes de pescadores tendo nas mãos um livro de Omar Hayham” (Ibidem, p. 168). Omar Khayyam era filósofo, poeta, matemático e astrônomo. Nasceu em Nishapur, no século XI.

16 “Agora és Leo Ferré, a cantar um poema de Aragon, Il n'aurait fallu / Qu'un moment de plus / Pour que la mort vienne / Mais une main nue / Alors est venue / Qui a pris la mienne" (Ibidem, p. 139). Leo Ferré (1916-1993), nascido em Mônaco, poeta e músico, célebre por suas canções anarquistas. Filiado ao partido comunista, teve sempre grande atuação política na França. Sobre as canções portuguesas, diz o narrador: "Rola sangrenta uma bola de sangue em Angola, começa Carlos Gil, as nossas canções revolucionárias são quase todas nostálgicas e tristes...”(Ibidem, p. 93)

17 "Apetecia-me que de repente Vittorio de Sica repetisse aqui $O$ Milagre de Milão, queria vê-los levantar das barracas e voar direitos ao céu..." (Ibidem, p. 99) Referência a uma célebre cena de Miracolo a Milano (1950), dirigida pelo italiano Vittorio de Sica; “...passa uma mulher esplendorosa que se parece com Monica Vitti e se calhar é ela mesma..." (Ibidem, p. 151), em mais uma das incertezas do narrador, e: "Está sempre à espera de lhe aparecer o Pirata dos sete mares, Errol Flynn, ou talvez James Mason e Ava Gardner, o Holandês errante e Pandora”. Erroll Flynn notabilizou-se pelos filmes de pirata e Mason e Gardner protagonizaram, em 1951, dirigidos por Albert Lewin, Pandora and the flying dutchman. Ainda digno de nota que Manuel Alegre dialoga com Pandora também em $A$ terceira rosa.

${ }^{18}$ As palavras são, na verdade, de Antero de Quental, tiradas do prefácio de 1872 da obra Primaveras românticas. Antero era do mesmo grupo de amigos de Eça de Queiroz que circulava por Coimbra: "Fomos todos assim, naquela encantada e quase fantástica Coimbra de há dez anos" (QUENTAL, Internet). De Antero de Quental também traz a ideia de repensar Portugal: “...está a fazer um trabalho de investigação sobre Antero de Quental (...) Somos os novos estrangeirados, também nós temos a obrigação de repensar Portugal de fora para dentro..." (Ibidem, p. 114).
}

Organon, Porto Alegre, nº 47, julho-dezembro, 2009, p.163 - 175 
E eis que o desconhecido de Paris sai do poema de Mário de Sá-Carneiro e entra no Café Dôme, exibindo na mão direita um exemplar do jornal 'A Bola', por sinal com uma fotografia do Eusébio na primeira página (...) O homem olha para o livro, despe a gabardina, senta-se, diz-me a senha, por acaso, ou talvez não, o princípio de um verso de Mário de Sá-Carneiro, 'Insônia roxa', a quem respondo com a contrasenha, 'A luz a virgular-se em medo’ (Ibidem, p. 147)19.

Logo após, Rafael parafraseia os versos: “Alguém caminha não sei onde nem para onde. Insônia roxa. A luz a virgular-se em som. E o desaparecido. O desaparecido dos domingos de Paris” (Ibidem, p. 148). O personagem também recorda: "Europa é um comboio de Paris para Genebra. Ou de Genebra para Milão. Ou de Milão para Roma. E de Roma para Genebra. E de Genebra para Paris. Vais dentro de um verso de Mário de Sá-Carneiro. Para uma grande capital” (Ibidem, p. 229). Dialoga, ainda, com Sá de Miranda ${ }^{20}$, Camões ${ }^{21}$, Guerra Junqueiro $^{22}$, Teixeira da Pascoaes ${ }^{23}$ e sua construção simbólica do país quietinho, Eugênio de Andrade $^{24}$, Camilo Castelo Branco ${ }^{25}$, Pero Vaz de Caminha ${ }^{26}$, Herberto Helder ${ }^{27}$, Fernão Mendes Pinto ${ }^{28}$ e Fernando Assis Pacheco ${ }^{29}$.

Seja pela vasta quantidade de nomes da literatura e cultura pincelados na obra, seja pela força política revolucionária que surge a partir desses, a literatura é mesmo receita para a descoberta de um país, aliás, textualmente citado na bela passagem, que traz mais alguns nomes das letras portuguesas:

Para se ter um país é preciso perdê-lo, só depois é que é nosso, só então se descobre e se percebe. Não tenho segredo, mas posso dar-vos uma receita: Amor de perdição, Mário, de Silva Gaio, A casa grande de Romarigães, a Peregrinação, a História de Portugal, de Oliveira Martins, talvez a melhor ficção portuguesa. E é claro: Bernardim, Sá de Miranda, Gil Vicente, Camões, o de Sôbolos rios, que já soube de cor. Sem esquecer as Memórias do capitão, do nosso Sarmento Pimentel, uma prosa fantástica. Descobrese Portugal pela língua, em certos livros nem é preciso lá ir, ele vem até nós (Ibidem, p. 117).

Em contraponto, há uma passagem que chama a atenção. São tão comuns as referências, página a página, que o narrador, quando não está apetecido pelas citações, quase pede desculpas ao leitor: "Por isso hoje não tenho paciência para as sutilezas das citações" (Ibidem, p. 99). O intertexto reconstrói Rafael, sempre à procura daquele convento da poesia de Rilke, espécie de pátria das línguas. Português fragmentado,

Tu próprio és ninguém, perdeste os sítios, o nome, a identidade, não tens a quem sorrir, a quem falar, sequer a quem perguntar se sabe onde podes dormir sem ter que mostrar o passaporte (...) Je est un autre,

\footnotetext{
${ }^{19}$ Referência ao poema Salomé, de 1913: Insônia roxa. A luz a virgular-se em medo, / Luz morta de luar, mais Alma do que a lua... / Ela dança, ela range. A carne, álcool de nua, / Alastra-se pra mim num espasmo de segredo... (SÁ-CARNEIRO, 2003, p. 51).

20 "Começou por Sá de Miranda: Comigo me desavim, / Sou posto em todo o perigo. / Não posso viver comigo / Nem posso fugir de mim (Ibidem, p. 60).

21 "Quando acordo, deitado no catre de madeira, sou Luís Vaz em prisões baixas, oiço uma voz afutricada que me grita: Por cá hoje, ó Dótor?" (Ibidem, p. 21).

22 "Havia um gajo que era coxo, costumava recitar o Melro, entrava no palco e anunciava: o Melro, de Guerra Junqueiro" (Ibidem, p. 51). Referência a um dos poemas mais famosos de Guerra Junqueiro (1850-1923), de 1879: "O melro, eu conheci-o: / Era negro, vibrante, luzidio, / Madrugador, jovial; / Logo de manhã cedo / Começava a soltar, dentre o arvoredo, / Verdadeiras risadas de cristal..." (JUNQUEIRO, s/d, p. 112).

23 "Ele não suporta o País quietinho de que falava Teixeira de Pascoaes. Onde estais, camaradas do não?" (Ibidem, p. 102).

24 "Posso deixar tudo mas certos livros não, há mesmo um, a Antologia do Eugênio de Andrade que ainda tem manchas de sangue e lama" (Ibidem, p. 147) e "Juntos e separados, como no verso de Eugênio de Andrade, vão os velhos companheiros..." (Ibidem, p. 252). Essa última é referência ao poema Viagem: "Iremos juntos separados, / as palavras mordidas uma a uma,/ taciturnas, cintilantes, / ó meu amor, constelação da bruma, / ombro dos meus braços hesitantes" (ANDRADE, 2001, p. 60).

25 "Sou Guilherme Lira, acabo de sair da novela de Camilo, não vou matar nenhum lente na estrada para Condeixa..." (Ibidem, p. 20) e “Agora Rafael é Simão, o do Amor de Perdição, vai à Verbena, ao Jardim Botânico, ao Bar das letras..." (Ibidem, p. 72).

26 "Já fui Pero Vaz de Caminha, redigi para D. Manuel a notícia do achamento desta nossa terra nova, a que o capitão pôs o nome de Vera Cruz, relatei-lhe suas belezas e maravilhas, as índias de vergonhas altas, çarradinhas, os índios de peito pintado como tabuleiros de xadrez, sempre mais amigos nossos que nós deles" (Ibidem, p. 63).

27 "Sobre um lençol mordido por flores com água, diz ele recitando Herberto Helder..." (Ibidem, p. 235). Referência ao poema $O$ amor em visita, de Helder.

28 "Descobrirás os cafés, os portugueses são gregários, o chinês de Fernão Mendes Pinto tinha razão, mesmo na desgraça encontram-se para se desentender" (Ibidem, p. 96). Referência às peregrinações de Pinto.

29 "Não posso estar serenamente, cantava o poeta Fernando Assis Pacheco. Rafael também não estava. Nem sereno, nem sossegado, nem no mosteiro dos monges da literatura" (Ibidem, p. 38). Fernando Santiago Mendes de Assis Pacheco (1937-1995) era poeta e jornalista (trabalhou na RTP). Escreveu em poesia e prosa, com especial dedicação temática à Guerra Colonial.
} 
esse outro és tu, ó estrangeiro, eu próprio que já não tenho eu, perdeste a pátria, perdeste o nome, estás a perder-te dentro de ti mesmo (Ibidem, p. 88).

desterritorializado, ele constrói no próprio exílio a sua pátria: "O exílio é uma pátria. Nós somos nós mesmos a nossa pátria" (Ibidem, p. 118). Rafael assiste com ironia à imobilidade de seu país: "Anda um bando de assassinos à solta em Portugal. Mas ninguém se mexia. Ruas e praças vazias. O corpo do General coberto de cal, Portugal coberto de cinza" (Ibidem, p. 163), enquanto os horrores da guerra nunca são exorcizados: "Perdoai-nos, senhor, perdoai-nos a uns e a outros, se é que é possível perdoar. Eu ouvi um preso que gritava, estava a ser queimado a maçarico. Por mais que faça não consigo esquecer. Haverá sempre em mim esse grito de um homem torturado na noite. Há guerras que não acabam nunca" (Ibidem, p. 65). O grotesco faz parte do cotidiano de uma nação sem referências, e mesmo antigos amigos agora estão ao outro lado da margem:

Há um alferes a tomar o pequeno-almoço com duas cabeças cortadas em cima da mesa, há um capitão que passeia em Luanda com orelhas humanas cortadas à cinta, há um antigo amigo meu, homem sensível, fundador de um grupo de teatro em Coimbra, que manda cortar os dedos das crianças negras em aldeias suspeitas. E todas as aldeias são suspeitas (Ibidem, p. 64).

A solidão de Rafael encaminha-o para o sem-sentido das coisas, quando só o que resta são os princípios mais arraigados: "Quando não temos mais nada temos a nossa honra" (Ibidem, p. 54). Ecos de uma biografia fantasiados num romance, ou vice-versa, Rafael traz um narrador desestabilizador, perdido entre suas lembranças, à procura de suas ausências:

e quando o vento agita as árvores não entendo a canção que canta em línguas desconhecidas, talvez seja isto o cosmopolitismo, a solidão das grandes cidades, o fascínio do norte e sua angústia, algo que me atrai e me atormenta, como um desterro dentro do desterro, ou uma pátria dentro da ausência dela (Ibidem, p. 95).

Talvez seja este o papel da resistência: um aprofundado aprimoramento no mundo das ideias que direcione a uma ação efetiva de mudança. Talvez seja esta a tarefa do narrador-autor-personagem Rafael, ao grifar a necessidade de diálogo com um leitor também acostumado à passividade que convive com os tempos de opressão. Talvez esteja no diálogo entre dois amigos a certeza de que os dias difíceis ficarão para trás, a certeza de que todos os caminhos levam a Lisboa, não importa onde se esteja, não importa como se viva: "Se calhar deveríamos ter seguido para Lisboa, arrisca Manuel Maria.

— Nós estamos sempre a seguir para Lisboa, responde Jorge Fontes (Ibidem, p. 253)"

Talvez tenha sido assim. Talvez. Narrativa de incertezas, teia construída a partir de textos outros, recordações e divagações que conduzem a um único caminho, muito maior que Lisboa, muito maior que Portugal: "A aventura também pode ser: não o que é mas o que podia ter sido e não chega nunca a ser. $\mathrm{O}$ acontecimento não acontecido" (Ibidem, p. 189). A aventura do que poderia ter sido, daquilo que um dia será: cidadãos sem vendas nem mordaças e uma pátria que respira liberdade.

Bibliografia

ALEGRE, Manuel. Rafael. 2. ed. Lisboa: Dom Quixote, 2004.

ANDRADE, Eugénio de. Antologia pessoal da poesia portuguesa. 5. ed. Lisboa: Campo das Letras, 2001. BOOTH, Wayne. "Our Many Different Businesses with Art". In: __ Critical Understanding. Chicago: University of Chicago Press, 1979.

. Retórica da ficção. Lisboa: Arcádia, 1980.

CEIA, Carlos (Org.). E-Dicionário de termos literários. Universidade Nova de Lisboa, Lisboa. Disponível em: http://www.fcsh.unl.pt/edtl/verbetes/M/mise_en_abime.htm. Acesso em 17 nov. 2007.

Filosofia. PUC-SP, São Paulo. Disponível em: http://www.pucsp.br/ filopuc/verbete/plotino.htm. Acesso em 20 set. 2008.

GRILO, João Mário. Anos de ouro do cinema português. RTC on-line, Lisboa. Disponível em: http://www.rtc.pt/videosrtp/artesletras.asp. Acesso em 11 nov. 2006.

JUNQUEIRO, Guerra. Obras de Guerra Junqueiro (poesia). Porto: Lello \& Irmão, s/d.

Organon, Porto Alegre, nº 47, julho-dezembro, 2009, p.163 - 175 
LORCA, Federico García. Conferências. Ganaderoslidia, Madrid. Disponível em http://74.125.45.104/search?q=cache:v-

uBvdWFJp0J:www.ganaderoslidia.com/webroot/pedefes/Federico\%2520Garc\%C3\%ADa\%2520Lorca.pdf+E stos+sonidos+negros+son+el+misterio,+las+ra\%C3\%ADces+Lorca\&hl=pt-BR\&ct=clnk\&cd=9\&gl=br.

Acesso em 14 out. 2007.

PLEKHANOV, Georgi. Bernstein e o Materialismo. Arquivo Marxista na Internet, Pacifica, Califórnia. Disponível em http://www.marxists.org/portugues/index.htm. Acesso em 27 set. 2008.

QUENTAL, Antero. Primaveras Românticas. Biblioteca Digital. Disponível em: http://web.portoeditora.pt/bdigital/pdf/NTSITE99_PrimRom.pdf. Acesso em 28 out. 2008.

RICOEUR, Paul. "Mundo do texto e mundo do leitor". In: __. Tempo e Narrativa. Campinas: Papirus, 1997. RILKE, Rainer. Simbologia e alquimia. Disponível em: http://simbologiaealquimia.blogspot.com/2007/12/rilke-em-paris.html. Acesso em 23 out. 2008.

RODRIGUES, Urbano Tavares. "A narrativa: seus caminhos e modelos em Portugal após a Revolução de Abril". In: Memória da Academia das Ciências de Lisboa. Classe de Letras, Tomo XXVII, Lisboa, 1988. p. 207-212. 